\title{
Theoretical Overview of Successional Considerations in Vegetation Management
}

\author{
by E.T. Oswald
}

\section{Abstract}

Forest succession most relevant to forestry originates following forest harvesting or wildfire. That following harvesting is most often also influenced by site preparation procedures for reforestation. The resultant vegetation succession is dependent on the type, degree, and timing of the disturbance, the site characteristics and conditions, and the microclimate. Subsurface organs, including roots, rhizomes, and stumps, allow most species of shrubs occurring on moist and wet forest sites to survive burning and crushing. Establishment and survival of some forbs, such as fireweed and bracken fern, are greatly facilitated by burning. Effective non-chemical techniques for providing desirable forest tree species a successional advantage over competing forest species are discussed. These involve different silvicultural systems, time of logging, type of scarification, time and degree of burning, time of planting, size of seedlings, and other reforestation considerations.

\section{Résumé}

La succession forestière la plus pertinente à la foresterie suit l'exploitation forestière ou les feux sauvages. Les méthodes de préparation de site pour le reboisement influencement plus souvent aussi la succession après l'exploitation. La succession végétative qui en résulte dépend du type, de l'intensité, et de la saison de la perturbation, des caracteristiques et des conditions de site, et du microclimat. Les organes souterrains, y compris les racines, les rhizomes, et les souches, permettent à la plupart des espèces d'arbrisseaux sur les sites forestiers humides et mouillés de survivre au brûlage et au broyage. Le brûlage aide beaucoup l'établissement et la survie de quelques herbes telles que l'épilobe à feuilles étroites et la fougère à l'aigle. On traite des techniques efficaces non chimiques pour donner l'avantage dans la succession aux espèces forestières désirables sur les espèces forestières en concurrence. Ces techniques comprennent des systèmes silvicoles différents, la saison d'exploitation, les types de scarifiage, la saison et l'intensité de brûlage, la saison de plantation, la grandeur des semis, et d'autres considérations silvicoles.

\section{Introduction}

The processes of plant succession, at least in the early phases, are governed initially by the factors that gave rise to the particular successional sequence and then by the biotic and abiotic factors of the site. Succession is still probably occurring in virtually all mature Canadian forests, even though the rate is very slow as stands attain maturity. Ecologically speaking, succession does not occur in a climax stand, but few if any of these occur in the forest environment of Canada. There are two categories of succession: primary, which occurs on land not previously supporting vegetation; and secondary, which occurs on land that formerly supported vegetation. Primary succession follows such natural events as newly exposed stream side alluvium, sand dune stabilization, upper part of landslides, volcanoes, and glacial scour tracks. To this can be added such man-caused disturbances as mine tailings, mine pits, and borrow pits where virtually all soil material previously influenced by vegetation has been removed, and in some cases where unnatural toxic chemicals may have been added to the substrate material. Secondary succession takes place following such severe disturbances as flooding, fire, forest harvesting, scraping and mixing of soil surface materials, and related events. In contrast to primary succession, the substrate in secondary succession has benefited from the presence of previous vegetation, and from the associated micro-fauna and -flora. These have influenced soil development processes by adding organic matter,

\footnotetext{
'Paper presented at the Joint Technical Session, "Vegetation management - problem or challenge," of the Forest Ecology, Forest Pest Management, and Silviculture and Tree Improvement Working Groups at the CIF/IFC Annual Meeting, Kananaskis, Alberta, October 1989.

${ }^{2}$ Research Scientist, Pacific \& Yukon Region, Forestry Canada, Victoria, B.C.
}

assisting in the breakdown and solution of soil materials, and in aeration. Secondary succession is of main interest to forest managers.

The primary objective of this paper is to examine secondary successional processes and to look at means of influencing them non-chemically to the advantage of the desired, usually planted, tree seedlings. Concurrent with examining means of reforestation, consideration must be given to environmental protection and costs. Much of the material presented refers specifically to the moist Englemann spruce - subalpine fir (ESSFc) biogeoclimatic subzone (Pojar et al. 1987; Utzig et al. 1983) of southeastern British Columbia. Most of the concepts, however, are applicable to other areas with a productive moist to wet environment where shrubs provide the main competition to tree growth. Some adjustment will probably be necessary to allow for the characteristics of the climate, terrain, and species of those other biogeoclimatic zones to obtain the desired results.

\section{Characteristic Causes of Secondary Succession}

\section{Wildfire}

Wildfire devastates vast forested areas in Canada every year. Man has limited control over wildfires, and cannot predict where or when they will occur, nor the amount of area that will be burned. We do have rudimentary fire prevention techniques, but these are more cosmetic than real as attested to by the amount of forest consumed each year. About all that can be done for fire control is to attempt suppression of the fire as soon as possible, thus reducing the size of it.

Several characteristics of wildfire can influence secondary succession. The time of year in relation to the phenology 
of the vegetation is important. Plants move much of the stored energy materials from the roots to the shoots during spring flush and flowering. Fires at this time of year can be more devastating to these plants than when they are again accumulating material in the root system or are dormant. Although fire rarely kills the root system of shrubs and rhizomatous forbs, the plants are slower to sprout and grow following spring burns than summer and fall burns. The intensity of the fire, which governs the amount of material burned on site, is influenced by such factors as type and age of vegetation, atmospheric and site moisture conditions, amount of fuel present, and the characteristics of the organic layers. Intense fires tend to burn deeper into the organic matter and can be more damaging to the root crowns and rhizomes of various plant species than light burns. Also, less intense fires tend to leave more patches of unburned vegetation over the area. Propagules from these patches, and those viable on the site, can then revegetate the burnt areas. The size of the burn can influence the intensity to some extent, but its greatest effect is it kills the vegetation over a larger area. This requires propagules from external sources destined for recolonization to be carried over greater distances (DeByle 1981).

The climatic conditions before and after the fire influence the intensity and severity of burn, and the species and rate of revegetation respectively. Insect and disease attacks can cause conditions conducive to burning. Fires can have a cleansing effect by burning insect and disease populations infesting trees or understory species which by themselves can affect vegetation succession.

\section{Forest Harvesting}

The many aspects of forest harvesting can each have a pronounced influence on subsequent vegetation succession. There are two main categories of logging, clearcut and selective cut, but there are gradations between the two that result in various successional patterns. Clearcutting of course removes all the trees from a block, while selective logging always leaves some trees for regeneration purposes and is expected to stimulate growth in residual trees. Clearcutting lends itself to a large variety of site preparation options, while such techniques are limited for selectively cut stands.

Regardless of the harvesting system used, the time of year during which the logging is conducted can influence the subsequent vegetation succession. During the winter, the ground is usually either frozen or covered with a protective blanket of snow so that less soil disturbance can be expected during winter logging. Also, the vegetation is dormant at this time and much of the stored energy is in the root systems. In the late summer and autumn the soil may be dry and firm, or wet and soft if it has rained, but most plants have restored much energy in the root systems, the seeds are mature, and the buds are set. Perhaps the harvesting time resulting in the most soil disturbance and disruption of the vegetation is in early spring when the soils are wet and soft and the vegetation is in a vulnerable phenological state.

A variety of clearcutting techniques are available, and the one selected most often depends on the size of the trees to be cut and the terrain features, particularly the steepness and stoniness of the topography. The size and shape of the opening created and the terrain characteristics not only influence the subsequent microclimate and potential for recolonization but the site preparation techniques that may follow. Medium to large trees on moderately sloping to level ground are often ground skidded. The skidding, and trails constructed for the operation, can be devastating to the non-merchantable vegetation. The feller/buncher technique is often used on level to somewhat sloping ground supporting relatively small trees. This procedure may be less detrimental to the soil and understory vegetation than ground skidding, especially when large rubber-tired equipement is used and the skidding is done from the same tracks as the feller/ buncher. High-lead logging is often done on steep slopes and usually causes less disturbance to the understory vegetation than ground skidding. Perhaps the least disturbing removal technique is the use of helicopters, but it is also the most expensive and is only used where other techniques are not suitable or available. Most current clearcutting is followed by some form of site preparation before planting, and the effects of this will be discussed later.

Selective logging is mostly conducted on moderately sloping to level ground. Selected trees are removed using techniques that will preserve a desired population of advanced regeneration and residual trees. On steeper slopes more of the advanced regeneration is mechanically disrupted during the log removal. The extent of canopy opening varies considerably, depending on the size and number of trees removed. In some cases only a few veterans may be removed, but selective logging grades toward clearcutting with only a few seed trees left in extreme cases. Some site preparation procedures used after clearcutting cannot be used with selective logging systems. Also when only seed trees are left, the next crop of trees originates from seed of these trees or from residual seed, while in selective logging the trees for the next crop are normally already present at the time of logging.

The amount of disturbance to the soil and vegetation caused by the selective logging operation is usually relative to the size and amount of wood removed. In most cases, however, the existing vegetation is readily available for refilling the canopy, and thus off-site species do not significantly enter the scene. Instead, shade tolerant species tend to be favoured, and the subsequent forest may consist of slower-growing tree species, which may be less desirable from a commercial view, than early seral invaders.

\section{Mechanical Site Preparation}

Site preparation for planting often follows logging, and there are several available methods (see Breadon 1987; MacKinnon et al. 1987; Bedford and McMinn 1989 for descriptions of implements available for mechanical site preparation). Although this normally pertains to clearcut logging, some techniques are not restricted to it. However, in selectively cut areas the advanced regeneration and residual trees must be maintained to ensure the next crop, and this restricts most common site preparation techniques. Exceptions can be found where only seed trees are left, and in strip cutting where certain procedures that will expose mineral soil can be used to improve the likelihood of adequate seedling establishment.

An assortment of plows are available for site preparation, all of which are designed to disrupt or remove root systems and/or expose mineral soil. Brush blades can be used on level to moderately sloping ground, and are commonly equipped with two to seven tines from $45 \mathrm{~cm}$ to $60 \mathrm{~cm}$ in length. They are effective in uprooting most trees, shrubs, and rhizomatous plants, although they are not recommended for large stumps or where boulders are present. On level 
ground the tines may be the only part penetrating the soil surface, while on sloping ground the blade usually scrapes the soil surface and can be used parallel or perpendicular to the contour.

When used with the contour, the tendency is to form a nearly level track which means the uphill side is cut into the slope, often exposing the nutrient-poor soil parent material. When used perpendicular to the slope, the possibility of creating a water-washed or gullied track increases with the length and steepness of the slope. The extent of erosion is related to the type of soil material and climate. V-plows are somewhat similar, but are used only on virtually level ground, and may not have the tines. Because of the topography on which they are used, it is not uncommon to create water catchment basins or troughs that are not conducive to growing trees. The dip-and-dive method, mostly used on steep topography, creates gouges, removing root systems and exposing subsoil material. Back-hoes or excavators are also used to form cleared patches for tree planting. They allow more control over the depth and size of clearing than most other machines.

A variety of discs are available, some of which are in continuous operation while others are cycled in and out to form mounds. Some discs are turned by a power source independent of the main machine, while others are passive similar to those used in agriculture. The use and effectiveness of these are largely dependent on the terrain and soil features and the amount of slash and organic matter present. The primary objective is to expose mineral soil in which seedlings can be planted or on which seeds can germinate, to aid slash reduction, and to retard the potential competing vegetation. These discs are probably most effective when the vegetation is in the vulnerable spring phenology stage, and will cause the most disruption when the soils are wet, but the degree of disruption is dependent on soil texture, depth, and drainage.

Mounders are site preparation mechanisms that are designed to overturn the soil surface, making various sized mounds (Bedford and McMinn 1989). They range in form from discs to tines on a revolving wheel. Mounders are most effective on level, stone-free soil for tree species that benefit from exposed mineral soil.

Drum rollers are another class of mechanism for site preparation. They vary from relatively simple liquid-filled drums equipped with fins that are pulled behind a tractor, to large self-powered machines. Their primary purposes are to knock down any remaining woody vegetation and to compress and break up the slash. One of the benefits is that slash and organic matter, which contain most of the site nutrients, are left distributed over the soil surface, and decomposition is somewhat facilitated by the compression, particularly on mesic to drier sites. The adverse effects of drum rollers include soil compaction, the degree of which is dependent on soil texture and moisture and the depth of organic material. A disadvantage is that the mineral soil, which is required by some tree species, is often not exposed. Few plant species are killed by drum rollers, but the tops of shrubs are knocked off and regrowth from the root crowns covered with debris, is often slower due to the cooler soil conditions resulting from the blanketing effect of the organic material.

Brush saws are used to remove the above-ground portion of competing plant species. Some of these are mechanical in the sense of larger equipment and are most often used indiscriminately for all vegetation along road ways and power lines. In forestry, most such vegetation removal is performed with hand-held or manual equipment, and is done around seedlings after they have been in the ground a few years. The effectiveness of this technique is still under review, but seems to depend on the site conditions and the species involved. It has the advantage that the severed plant material is left on the site and is thus available for nutrient release; however, this can also result in cooler soils depending on the depth of slash, aspect, etc. As with other techniques, it may be most effective in retarding competing vegetation when performed during the early leaf expansion and flowering stage. In some cases the process requires repetition after a few years to give the seedlings a second chance to stay above the shrub growth.

Severe scarification should only be considered when adequate control of competing vegetation cannot be achieved through other means. Site preparation techniques that will disrupt the vegetation without serious soil disturbance are recommended because seedlings planted in nutrient-poor compacted mineral soil generally do not grow well. Current procedures that result in little soil disturbance but still disrupt the vegetation, are generally not suited to moderate and steeply sloping terrain. It appears a mechanism that would remove the above-ground part of the vegetation, perhaps grind it up and redistribute it on the site, but would also expose some mineral soil, would be ideal. Such a method would result in cooler soils than with burning, which tends to retard developments of most species, but the nutrients would be available for release over time and the trees would benefit in the long term. A seedling may suffer from the cool soils, but will enjoy a few years with little competition, during which period it can get established.

\section{Broadcast Burning}

A common site preparation technique, especially in mountainous topography, is to broadcast burn sites with brush or heavy debris following clearcutting (Chroscieweicz 1989) or where seed trees are left (Kilgor and Curtis 1987). It is most desirable to burn as soon as the slash dries out after logging, which is usually within one year. Sometimes unfavourable weather, or other factors, may prevent this from happening. In general, however, the weather can be monitored and the most optimal moisture conditions for the desired intensity of burn can be obtained during most years. Spring burning can be more detrimental to the existing vegetation because of the vulnerable phenological state than with fall burning when most plants are dormant. In most moist and wet environments, however, the slash usually does not dry sufficiently to allow spring burning, or if so at a lower intensity than with summer and fall burns.

Other than the volatilization of some nutrients and other chemicals, and the formation of ash that can be blown off the site, burning is not as detrimental to the site as many mechanical site preparation techniques. Potential competing vegetation is removed to ground level, but root crowns, rhizomes, and some seeds most often survive and are sometimes stimulated. Fire is also useful in reducing the slash, which makes planting easier, aids nutrient release, and can be effective in insect and disease control in infested areas. The blackened soil surface resulting from burning increases the soil temperature for a few years, which usually aids plant growth unless the soil becomes hot enough to damage young succulent tissue. Though there are several benefits of burning, and it will probably remain a common site preparation option, restrictions should apply to reduce the amount of burning because of the consequent atmospheric pollution. 
The most undesirable aspects of burning are the amount of plant nutrients lost through volatilization the amount of smoke emitted, and the lack of mineral soil exposure. Local residents are becoming increasingly opposed to the obnoxious smoke emissions in areas where prescribed burning is a common practice. Another procedure for burning is to pile and burn, but most of the detrimental aspects of broadcast burning are still present, and it may be applicable only to certain site types.

\section{Vegetation Management}

There is no single site preparation technique suitable for all purposes. It is essential to know the characteristics of the site to be treated and the microclimatic conditions preceding and at the time of site preparation. The actual techniques for managing vegetation likely to compete with the desired tree species will vary with the site conditions and species to be dealt with. Whatever site preparation techniques are employed will influence the successional sequences, particularly in the initial stages.

The following discussion is focused on the moist Engelmann spruce - subalpine fir (ESSFc) subzone for an example. The ESSF zone is the highest in elevation of the biogeoclimatic zones in which commercial forest harvesting is conducted; it has a relatively cold climate, and occurs mostly on moderate to steeply sloping, often rocky, terrain. The ESSFc subzone is moist with a fairly even distribution of precipitation, and receives a lot of snow during a nearly six-month winter. It often occurs on northerly aspects and on sites with cold air drainage where evapotranspiration and organic matter decomposition are reduced at lower elevations in otherwise drier climates. The commercial forests of highest elevation are mostly on south-facing slopes. Between these extremes, the ESSFc can occur on all aspects.

The normal, or stable, vegetation for this subzone is Englemann spruce (Picea engelmannii Parry) and subalpine fir (Abies lasiocarpa (Hook.) Nutt.) with an understory of false azalea (Menziesia ferruginea Sm.), white-flowered rhododendron (Rhododendron albiflorum Hook.), black blueberry (Vaccinium membranceum Dougl. ex Hook.) and a sparse cover of forbs and mosses. Subalpine fir is often the most abundant tree species in the lower tree layers, largely through layering, thus the tendency is towards domination by this species. However, Englemann spruce lives longer and usually has enough regeneration to take advantage of canopy openings. The azaelea and rhododendron often form a moderately open and spreading cover one to two meters in height, while the blueberry remains lower. Disruption of the tree canopy tends to promote growth of the shrubs, as they can tolerate full sunshine as well as shade on the usually cold and moist sites in this biogeoclimatic subzone.

When the trees are harvested, most often by clearcutting, it is the usual practice to perform some type of site preparation on medium and highly productive sites before planting unless there is good stocking of acceptable advance regeneration. It is not uncommon on moderate to steep slopes to cut skid trails in a herring-bone pattern with a blade for ground skidding, and to cable log the steepest slopes. Currently, the common practice is to broadcast burn after cutting, and to plant soon thereafter. Burning removes the slash and above-ground plant material, but rarely kills the root systems of shrubs and rhizomatous forbs. The blackened soil surface warms faster in spring and remains warmer than where burning is not conducted. Rhododendron and azalea begin resprouting from rootstocks within a year, and blueberry regenerates from its rhizomes. Along with these species, black twinberry (Lonicera involucrata (Richards.) Banks. ex Spreng.) Utah honeysuckle (Lonicera utahensis Wats.), red raspberry (Rubus idaeus L.) and elderberry (Sambucus racemosa L.) which were sparsely distributed prior to logging, recolonize from seed and rootstocks to form a prominent shrub layer. Fireweed (Epilobium angustifolium L.) is the most conspicuous forb following fire; it may or may not be present in the stand prior to logging, but can start from seed blown in from the surrounding area, and then reproduces by means of a perennial spreading root system to form a fairly dense cover a meter or more in height in two to three years. Arnica (Arnica spp.) and ragwort (Senecio spp.) may also be prominent.

Drastic scarification techniques, such as brush blades that cut lines as close together as possible leaving a pile of debris between the lines, are normally used only on backlog non-sufficiently restocked (NSR) sites. In addition to the root systems of the various living plants, surface organic material is often removed by these techniques, leaving nutrient-poor subsurface soil material in which to plant tree seedlings. The equipment used is usually rather heavy, resulting in soil compaction along the tracks, but there is sufficient room to plant at least two rows of seedlings along the cut without planting in the compacted material.

Following blade scarification, a variety of forbs, dominated most often by fireweed, are the main colonizers on the cut faces. The forb development is slow in the cut, but can be rapid on the side-cast. Shrubs are much slower to become established. Seed is generally produced by plants surviving in the ridges made between the cut lines, but seed for recolonization is also transported in from outside sources. Even if the seed is deposited on the exposed subsoil of cut tracks, germination and survival are poor. Rhizomes of shrubs such as blueberry, can become established in the side-cast material. Natural tree seedlings originating from imported seed can become established on the cut face in about three years. Tree seedlings planted on the cut-bank and central portion of the cut often grow slowly; they do much better in the side-cast.

Given these characteristics of the vegetation and possible site preparation procedures, what are the best options for getting a viable forest, i.e., one in which the seedlings can out-grow the other vegetation, re-established after harvesting? In the ESSFc subzone the soil remains moist virtually all year, but is wet during snow melt and following rains. During June and July the vegetation is flushing and the soils are likely to contain enough moisture to be soft, thus harvesting at this time would probably be the most disruptive to the soil and deleterious to the remaining vegetation. Cable logging would be the most likely method on the steeper slopes and ground skidding on the moderate slopes.

If logging does not result in sufficient shrub control then burning or scarification may be required. Burning would require time for the slash to dry. The optimal time would be during the following spring shortly after bud break by the competing vegetation, but high moisture in the slash might preclude it. Therefore, burning should be done in the autumn following spring logging when conditions are suitable for an intense burn. In the case of spring burning, planting should follow as soon as possible after burning, but with autumn burning the planting should be done the following year after the soils have warmed. Burning and/or scarification promote colonization and rapid development by fireweed. Seeds of fireweed can germinate the same year and the root systems 
may continue growing during much of the winter. In three to four years fireweed dominates the sites. Shrubs, depending on the amount of disruption during logging or the intensity of fire, may not become evident for a year or two, and usually require more than four years before becoming a competitive threat to the seedlings. Spruce seedlings often appear to derive benefit from the protective cover of other plants. On nearly level, boulder-free terrain, consideration could be given to using a finned drum roller immediately after logging to assist the break down of shrub crowns and compact the slash for easier planting.

An important aspect of vegetation management for forest renewal is the use of high quality seedlings. Production procedures have improved over the last decade, so that more good quality seedlings are available. Planting is best done when the soil is moist and warm to facilitate seedling establishment. In moist environments, there is usually not a problem and planting can be done throughout the summer. For several species, good one-year old seedlings can be hot-lifted and planted without a winter storage period. Such seedlings appear to have better root growth, especially when planted in early to mid summer, than seedlings that have been in cold storage. Late fall planting is probably the worst time because the seedlings do not have time for adequate root growth or to adapt to winter conditions. A good, healthy seedling of the proper species and provenance for the site, planted and established shortly after whatever vegetation control measures are used, will most often out-compete the other vegetation. This can apply to slower growing spruce, hemlock, and fir seedlings, which are late seral species, as well as the faster growing pine, larch, and Douglas-fir which are mostly early seral species.

Where suitable advance regeneration is present following logging, consideration should be given to reforestation by natural means. Natural regeneration is often unpredictable in terms of subsequent species composition, density, and distribution, and commercially less desirable species may be favoured. An advantage of natural regeneration, however, is that more mixed populations of species often result as opposed to the usual monoculture common in plantations. Thinning may be required if natural regeneration is too abundant, as well as in plantations where natural fill-in occurs among the planted seedlings.

Less productive sites, particularly those in the drier subzones, may be left for natural regeneration. This may be facilitated by using disks or chains to expose mineral soil on level to gently sloping topography, but often advance regeneration is present and will negate site preparation procedures. Organic matter on these sites is rarely deep enough to create a problem. If there is adequate seed, germination and establishment can occur during the first year or so, in which case the seedlings usually can compete satisfactorily with the other vegetation. Where planting is done, "screefing" normally clears the planting spot of vegetation and organic matter.

\section{Conclusions}

For reforestation and vegetation control it is essential to know the characteristics of the site and how various logging and site preparation techniques influence these characteristics under the relevant microclimatic conditions.
Although herbicides and prescribed burning have adverse environmental consequences, and thus their use should be kept to a minimum, they will continue to be used where other techniques are not feasible.

There are possible means of achieving adequate site preparation for reforestation following logging or wildfires that are not environmentally destructive, and may even reduce the cost of reforestation. In the case of logging, those activities that are disruptive to the associated vegetation, e.g. ground skidding, prescribed burning, and mechanical site preparation techniques, should be done during the spring development stage of the competing vegetation. There is a net loss of energy from the root system to the developing shoots at this time and disruption of the shoots during this phenological phase will be more detrimental to competing plants than later when the energy has been restored to the root system. However, the ground vegetation may be wet at this time, which hinders burning and mechanical techniques may result in more soil disturbance than is desired. This may make it necessary to plan the events on a short-term basis dependent on the weather conditions.

There are desirable aspects to natural regeneration where such can be achieved but the adequacy of this usually cannot be predicted except where suitable advance regeneration is present following logging. For this reason it is most often advisable to restock the site by planting even if thinning may be required at a later date. Where planting is prescribed following logging or wildfires, good planting stock of the correct species and provenance for the site is essential. In moist and wet sites where the soils never dry out, planting can be done at any time during the snow-free period. The best seedling establishment results from planting using hot-lifted stock during the late spring and early summer after the soils have warmed, but well before any fall frost. Seedlings planted in this manner exhibit better root egress and adaptation to site conditions, particularly as pertains to winter hardiness, than seedlings that were held in winter storage or planted too late in the year.

\section{References}

Bedfore, L. and R.G. McMinn. 1989. Trials to appraise the biological effectiveness of mechanical site preparation equipment in British Columbia. Proc. IUFRO S1.05-12 Northern Forest Silviculture and Management Working Party, 1989 Symposium. In press.

Breadon, R.E. 1987. Site preparation equipment in British Columbia. FRDA Rpt. 016. 106 pp.

Chrosciewicz, Z. 1989. Postcut burning and black spruce regeneration. Proc. IUFRO S1.05-12 Northern Forest Silviculture and Management Working Party, 1989 Symposium. In press.

DeByle, N.V. 1981. Clearcutting and fire in the larch/Douglas-fir forests of western Montana - A multifaceted research summary. USDA For. Ser. Gen. Tech. Rpt., INT-99. 73 pp.

Kilgor, B.M. and G.A. Curtis. 1987. Guide to understory burning in Ponderosa pine - larch - fir forest in the intermountain west. USDA For. Ser. Gen. Tech. Rpt. INT-2333. 39 pp.

MacKinnon, A., L. Bedford, and J. Maxwell. 1987. A guide to the use of mechanical site preparation equipment in north central British Columbia. FRDA Hndbk 002. 63 pp.

Pojar, J., K. Klinka and D.V. Meidinger. 1987. Biogeoclimatic ecosystem classification in British Columbia. Forest Ecol. and Manag. 22: 119-154.

Utzig, G.F., P.G. Comeau, D.I. Macdonald, M.V. Ketcheson, T.F. Braumandl, A.R. Warner and G.W. Still. 1983. A field guide for identification and interpretation of ecosystems in the Nelson Forest Region. B.C. Min. For. 77 pp. 